\title{
Task 21 - Field Demonstration of Ex-Situ Biological Treatability of Contaminated Groundwater at the Strachan Gas Plant
}

\section{RECEIVEO \\ JULL 30 O997 \\ Topical Report \\ $0 \mathrm{ST}$ \\ March 1997}

Work Performed Under Contract No.: DE-FC21-93MC30098

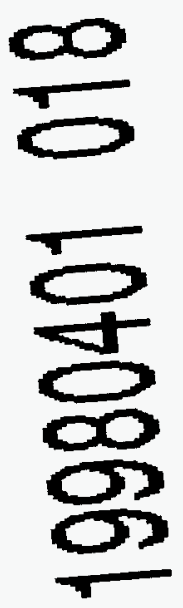

For

U.S. Department of Energy

Office of Fossil Energy

Federal Energy Technology Center

Morgantown Site

P.O. Box 880

Morgantown, West Virginia 26507-0880

By

Energy \& Environmental Research Center

University of North Dakota

P. O. Box 9018

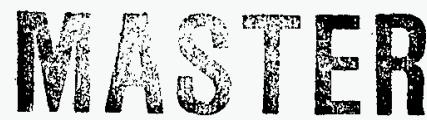

Grand Forks, North Dakota 58202-9018 


\section{Disclaimer}

This report was prepared as an account of work sponsored by an agency of the United States Government. Neither the United States Government nor any agency thereof, nor any of their employees, makes any warranty, express or implied, or assumes any legal liability or responsibility for the accuracy, completeness, or usefulness of any information, apparatus, product, or process disclosed, or represents that its use would not infringe privately owned rights. Reference herein to any specific commercial product, process, or service by trade name, trademark, manufacturer, or otherwise does not necessarily constitute or imply its endorsement, recommendation, or favoring by the United States Government or any agency thereof. The views and opinions of authors expressed herein do not necessarily state or reflect those of the United States Government or any agency thereof. 


\section{TABLE OF CONTENTS}

LIST OF FIGURES $\ldots \ldots \ldots \ldots \ldots \ldots \ldots \ldots \ldots \ldots \ldots \ldots \ldots$

LIST OF TABLES $\ldots \ldots \ldots \ldots \ldots \ldots \ldots \ldots \ldots \ldots \ldots \ldots \ldots \ldots$

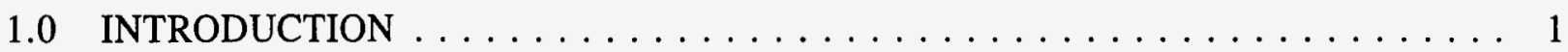

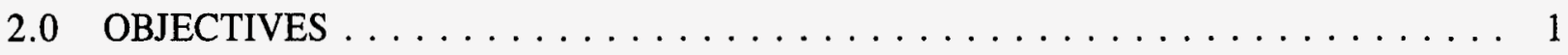

3.0 GROUNDWATER CHARACTERIZATION $\ldots \ldots \ldots \ldots \ldots \ldots \ldots \ldots$

4.0 EX SITU GROUNDWATER TREATMENT $\ldots \ldots \ldots \ldots \ldots \ldots \ldots \ldots$

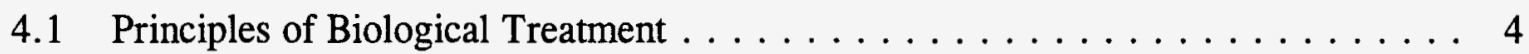

4.2 Ex Situ Treatment Process Description $\ldots \ldots \ldots \ldots \ldots \ldots \ldots \ldots \ldots$

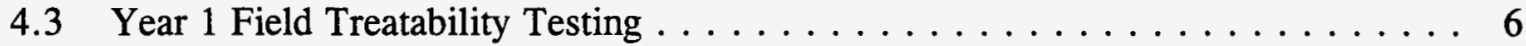

4.3.1 Equipment Description and Operation $\ldots \ldots \ldots \ldots \ldots \ldots$

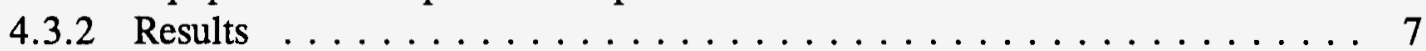

4.4 Year 2 Treatability Testing $\ldots \ldots \ldots \ldots \ldots \ldots \ldots \ldots \ldots$

4.4.1 Equipment Description and Operation ............... 9

4.4 .2 Results ............................ 10

5.0 SUMMARY AND CONCLUSIONS $\ldots \ldots \ldots \ldots \ldots \ldots \ldots \ldots$

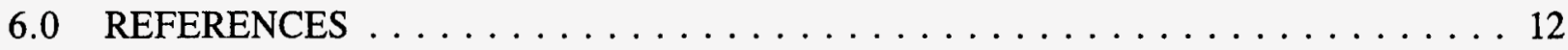




\section{LIST OF FIGURES}

1 Conceptual nitrification-denitrification process diagram $\ldots \ldots \ldots \ldots$

2 Two-stage $\mathrm{RBC} \ldots \ldots \ldots \ldots \ldots \ldots \ldots \ldots \ldots \ldots \ldots \ldots$

3 BTEX influent and effluent concentrations versus time at 800-L/day feed rate in Year 1 . 9

4 BTEX influent and effluent concentrations versus time at 1800 - and $2800-\mathrm{L} /$ day feed rate in Year $2 \ldots \ldots \ldots \ldots \ldots \ldots$

\section{LIST OF TABLES}

1 Results of Supplemental Characterization Analyses

Strachan Gas Plant Groundwater . . . . . . . . . . . . . . . . . 3

2 Routine System Maintenance Performed During Strachan

Groundwater Treatability Studies . . . . . . . . . . . . . . . . 8

$3 \quad$ RBC Treatability Test Results at 800 -L/day Influent Rate $\ldots \ldots \ldots \ldots \ldots$

$4 \quad$ RBC Treatability Test Results at $1800-\mathrm{L} /$ day Influent Rate $\ldots \ldots \ldots \ldots$

$5 \quad \mathrm{RBC}$ Treatability Test Results at 2800 -L/day Influent Rate $\ldots \ldots \ldots \ldots \ldots$ 


\section{FIELD DEMONSTRATION OF EX SITU BIOLOGICAL TREATABILITY OF CONTAMINATED GROUNDWATER AT THE STRACHAN GAS PLANT}

\subsection{INTRODUCTION}

Recognizing the potential impacts of sour gas plant operations on the subsurface environment, the Canadian Association of Petroleum Producers (CAPP), formerly the Canadian Petroleum Association (CPA), and Environment Canada initiated a multiphase study focusing on research related to the development and demonstration of remedial technologies for soil and groundwater contamination at these facilities. The first phase of the project, completed in 1990, consisted of a comprehensive review of all soil- and groundwater-monitoring data submitted to Alberta Environment by sour gas plants in accordance with the Canadian Clean Water Act (1980). That review indicated that all but one of the 45 sour gas plants for which data were available exhibited some form of impact on soil and groundwater quality. The study identified the most frequently occurring contamination situations at the sites and classified them according to sources and types of contaminants and the hydrogeological characteristics of the contaminated setting. The project steering committee subsequently selected the Strachan Gas Plant, located near Rocky Mountain House, Alberta, Canada, as a field research and remediation technology demonstration site.

The next phase of the study consisted of a detailed review of available subsurface remedial technologies that could be applied to specifically identified problems. Established and innovative technologies were assessed, and those showing the most promise for dealing with the type of contamination situations usually found at sour gas-processing facilities were recommended for further development and/or demonstration.

The current phase of work involves the development, evaluation, and demonstration of selected remediation technologies to address subsurface contamination of sediments and groundwater at sour gas treatment plants. The primary emphasis of the program is on the presence of natural gas condensate in the subsurface.

This report presents the results of pilot-scale biological treatability testing that was performed at the Gulf Strachan Natural Gas Processing Plant in Rocky Mountain House, Alberta, Canada.

\subsection{OBJECTIVES}

Contaminated groundwater from the Strachan Gas Plant is presently being pumped to the surface through several recovery wells in order to control contaminant migration. The recovered groundwater is then directed to the existing pump-and-treat system that consists of oil-water separation, iron removal, hardness removal, and air stripping prior to reinjection.

To assess alternative treatment options, pilot-scale biological treatability testing of contaminated groundwater was conducted. The goals of biological treatability testing were as follows: 
- Evaluate process stability in treating groundwater without pretreatment for iron and hardness reduction

- Evaluate the removal of organic contaminants

- Demonstrate biological nitrification

- Demonstrate denitrification of nitrified effluents

- Evaluate the selected process in the field under a variety of operating conditions

- Assess the need for further treatment to satisfy interim Canadian water quality criteria (CCME, 1991)

\subsection{GROUNDWATER CHARACTERIZATION}

An effective groundwater remediation effort requires a thorough understanding of the physical and chemical character of the contaminants present. Prior to the selection of the biological system for evaluation, Strachan groundwaters were subjected to supplemental characterization analyses. Table 1 shows the results of the supplemental analyses performed on groundwaters from Recovery Wells RW-8 and RW-13.

These data generally agree with previous monitoring analyses conducted on groundwaters at the Strachan site. However, total Kjeldahl nitrogen (TKN) was about half of what was previously noted. The TKN in the groundwaters was primarily in the form of ammonia, indicating the possible biological reduction (ammonification) of suspected organic nitrogen compounds (amines and amine degradation products).

Over 50 metals were scanned during a qualitative screening using inductively coupled argon plasma (ICAP) techniques. Those metals found in detectable quantities in the Strachan groundwater are listed in Table 1; all were at concentrations below current U.S. Environmental Protection Agency (EPA) drinking water standards.

Organic contamination as measured by chemical oxygen demand (COD) was 110 and $73 \mathrm{mg} / \mathrm{L}$ in groundwaters from RW-8 and RW-13, respectively. The COD can most likely be attributed to dissolved natural gas condensates. Previous analyses indicated typical benzene, toluene, ethylbenzene, and total xylene (BTEX) concentrations of $1200,600,700$, and $4500 \mu \mathrm{g} / \mathrm{L}$, respectively.

All gas chromatography-mass spectroscopy (GC-MS) identifications were tentative, based only on mass spectra. Identifications of common species such as alkylbenzenes, phenols, indole, alkanes, and elemental sulfur $\left(\mathrm{S}_{8}\right)$ are very certain. The identifications of other species (mostly cyclic alkanes) are more tentative, but are fairly certain to be the correct compound class and molecular weight. 


\section{TABLE 1}

Results of Supplemental Characterization Analyses

Strachan Gas Plant Groundwater (all units in $\mathrm{mg} / \mathrm{L}$, except $\mathrm{pH}$ and conductivity)

\begin{tabular}{lcc}
\hline Constituent/Parameter & RW-8 & RW-13 \\
\hline pH & 6.9 & 6.9 \\
Alkalinity $\left(\mathrm{as} \mathrm{CaCO}_{3}\right)$ & 460 & 550 \\
Hardness $\left(\mathrm{as} \mathrm{CaCO}_{3}\right)$ & 465 & 465 \\
Ammonia & 2.4 & 34 \\
Nitrate & $<1$ & 9.7 \\
Nitrite & $<1$ & 4.5 \\
Total Kjeldahl Nitrogen (as N) & 5.4 & 34 \\
Phosphate & $<1$ & 1.6 \\
Sulfate & $<1$ & 140 \\
Chloride & 27 & 24 \\
Barium & 0.6 & 0.3 \\
Calcium & 140 & 140 \\
Iron & 13 & 1 \\
Magnesium & 28 & 28 \\
Manganese & 2.5 & 0.8 \\
Phosphorus & 0.06 & 0.3 \\
Potassium & 0.9 & 2.9 \\
Selenium & $<0.1$ & 0.2 \\
Sodium & 55 & 60 \\
Strontium & 0.2 & 0.3 \\
Sulfur & 12.8 & 116 \\
Silicon & 3.1 & 4.1 \\
Zinc & 0.4 & $<0.003$ \\
Total Inorganic Carbon & 130 & 120 \\
Total Organic Carbon & 40 & 55 \\
Chemical Oxygen Demand & 110 & 73 \\
Total Dissolved Solids & 710 & 760 \\
Conductivity, mmho/cm & 0.9 & 0.7 \\
\hline
\end{tabular}

More detailed examinations of the organic constituents in the groundwaters were conducted at Energy \& Environmental Research Center (EERC) laboratories. Samples of RW-8 and RW-13 groundwaters and a sample of the natural gas condensate floating on the water table at RW-13 were subjected to GC-MS and gas chromatography-atomic emission detection (GC-AED) analyses.

The condensate sample collected from RW-13 appeared to have been depleted of species on the more water-soluble end, such as benzene and toluene, and contained, in decreasing order by concentration: $\mathrm{C} 2$ to $\mathrm{C} 5$ alkylbenzenes (mostly $\mathrm{C} 2$ and $\mathrm{C} 3$ ); $\mathrm{C} 6$ to $\mathrm{C} 22 n$-alkanes (mostly $\mathrm{C} 7$ with lesser amounts as the molecular weight increased) and smaller amounts of related branch alkanes; $\mathrm{C} 6$ to $\mathrm{C} 9$ cyclic alkanes (mostly $\mathrm{C} 7$ and $\mathrm{C} 8$ ); and elemental sulfur. 
GC-AED analysis indicated that the condensate sample did not contain significant nitrogencontaining organics but did have sulfur-containing organics. The sample exhibited a large elemental sulfur peak as well as approximately 30 more volatile sulfur-containing organics. While the chromatographic behavior was consistent with alkylthiophenes, alkylbenzothiophenes, and alkyldibenzothiophenes, the concentration of the sulfur-containing organics was too low to allow GC-MS identification without significant additional effort.

The groundwater samples were extracted with methylene chloride after $\mathrm{pH}$ adjustment to 12 to obtain the base-neutral fraction and again after $\mathrm{pH}$ adjustment to 2 to obtain the acid fraction. The extracts were then evaporated to $100 \mu \mathrm{L}$ for analysis.

Essentially all of the organics extracted from the groundwaters were in the base-neutral fraction, and none of the more obvious acids, such as phenol, were detected by GC-MS. As would be expected, the organics in the water reflected the organics in the natural gas condensates. RW-8 groundwater contained mostly $\mathrm{C} 2$ and $\mathrm{C} 3$ alkylbenzenes and much lesser amounts of $n$-alkanes. RW-13 groundwater contained mostly C2 and C3 alkylbenzenes, lesser amounts of $n$-alkanes and branched alkanes, and elemental sulfur. A third groundwater sample, collected from RW-12, contained toluene, $\mathrm{C} 2$ and $\mathrm{C} 3$ alkylbenzenes, elemental sulfur, and naphthalene and $\mathrm{C} 1$ naphthalenes.

GC-AED analyses of the groundwater extracts for sulfur-containing species yielded results similar to those obtained for the condensates. RW- 8 contained about 30 significant organic sulfurcontaining compounds, mostly in the more volatile BTEX range, as well as a lesser amount of elemental sulfur. RW-13 also showed several sulfur-containing organics (the pattern was dominated by species less volatile than those found in RW-8) and a very large elemental sulfur peak.

\subsection{EX SITU GROUNDWATER TREATMENT}

The chemical characteristics of the groundwater at the Strachan Gas Plant indicated that an ex situ remediation technology should address not only dissolved volatile and semivolatile organic contamination from natural gas condensates, but also nitrogenous compounds resulting from the use of amine-based process chemicals. The following sections provide discussions of the principles of biological treatment with regard to these contaminants and the development of a remediation system for effective remediation of contaminated groundwater.

\subsection{Principles of Biological Treatment}

Biological treatment is used to remove biodegradable organic compounds and certain inorganic constituents such as ammonia from water. Biological processes utilize microorganisms to biochemically oxidize dissolved contaminants to carbon dioxide, water, and other end products. A simplified biochemical equation for the aerobic utilization of organic matter is represented by (Reynolds, 1982):

$$
\text { Organic matter }+\mathrm{O}_{2}^{\text {bacteria }} \rightarrow \mathrm{CO}_{2}+\mathrm{H}_{2} \mathrm{O}+\text { cell growth }+ \text { other end products }
$$


"Other end products" include $\mathrm{NH}_{4}{ }^{+}, \mathrm{NO}_{2}{ }^{-}, \mathrm{NO}_{3}{ }^{-}$, and $\mathrm{PO}_{4}{ }^{3-}$. The process is carried out by singlecelled bacteria that are collectively referred to as heterotrophs, bacteria that utilize organic carbon as an energy source.

Under proper environmental conditions, ammonium $\left(\mathrm{NH}_{4}{ }^{+}\right)$is biochemically oxidized through a process known as nitrification. The bacteria responsible for nitrification are autotrophs, those that use inorganic carbon, such as carbon dioxide, as an energy source. Nitrification is a twostep process where $\mathrm{NH}_{4}{ }^{+}$is oxidized first to nitrite $\left(\mathrm{NO}_{2}{ }^{-}\right)$, then to nitrate $\left(\mathrm{NO}_{3}{ }^{-}\right)$. Ammonium is oxidized to nitrite by Nitrosomonas bacteria under aerobic conditions as follows:

$$
2 \mathrm{NH}_{4}^{+}+3 \mathrm{O}_{2} \rightarrow 2 \mathrm{NO}_{2}^{-}+4 \mathrm{H}^{+}+2 \mathrm{H}_{2} \mathrm{O}
$$

The nitrites are then oxidized to nitrate by Nitrobacter bacteria according to the following:

$$
2 \mathrm{NO}_{2}^{-}+\mathrm{O}_{2} \rightarrow 2 \mathrm{NO}_{3}^{-}
$$

The overall nitrification reaction is as follows (EPA, 1975):

$$
\mathrm{NH}_{4}^{+}+2 \mathrm{O}_{2} \rightarrow \mathrm{NO}_{3}^{-}+2 \mathrm{H}^{+}+\mathrm{H}_{2} \mathrm{O}
$$

The nitrate formed may be used as an alternate electron acceptor in biological denitrification processes where the nitrate is first reduced to nitrite and then to nitrogen gas.

Denitrification processes are carried out by a broad range of facultative heterotrophic bacteria that use organic carbon as an energy source and nitrate as an alternate electron acceptor under anoxic conditions. Denitrification is also a two-step process that involves the reduction of nitrate to nitrite and then to nitrogen gas, according to the following equations (EPA, 1975):

$$
\begin{aligned}
& 3 \mathrm{NO}_{3}+\mathrm{CH}_{3} \mathrm{OH} \rightarrow 3 \mathrm{NO}_{2}^{-}+\mathrm{H}_{2} \mathrm{O}+\mathrm{H}_{2} \mathrm{CO}_{3} \\
& 3 \mathrm{NO}_{2}^{-}+1.5 \mathrm{CH}_{3} \mathrm{OH} \rightarrow 1.5 \mathrm{H}_{2} \mathrm{CO}_{3}^{-}+3 \mathrm{H}_{2} \mathrm{O}
\end{aligned}
$$

The above reactions show methanol as the carbon source, although many organic compounds can serve as the carbon source for denitrification.

\subsection{Ex Situ Treatment Process Description}

Based on the characteristics of Strachan Gas Plant groundwater, an attached growth system with combined carbonaceous and nitrogenous removal capabilities was selected for evaluation. An attached growth system was selected because of the volatile natural gas condensate constituents in the groundwater, which would readily volatilize under conditions where aeration would be utilized. Additionally, elevated levels of nitrogenous compounds, primarily ammonia, in the groundwater indicated that nitrogen removal would also be an important consideration. The treatment system consisted of two-stage coupled nitrification-denitrification rotating biological contactors (RBCs). After completing testing at the bench-scale level, a pilot-scale unit of the same coupled nitrification-denitrification concept was selected for on-site evaluation at the gas-processing facility. 
Figure 1 is a conceptual diagram of the coupled nitrification-denitrification process. Groundwater contaminated with organics and ammonia provides influent to the system. Organic matter is oxidized in the first stage under anoxic conditions. Denitrification is also accomplished in the first stage, through utilization of nitrate that is produced in the second stage. The nitrate is formed in the second stage through the oxidation of ammonia (nitrification) under aerobic conditions. Recycle between the two stages provides removal of both carbonaceous and nitrogenous contaminants in a single treatment system.

\subsection{Year 1 Field Treatability Testing}

\subsubsection{Equipment Description and Operation}

The reactors of the pilot-scale unit consisted of epoxy-coated steel basins with an operating volume of approximately 180 liters for the first stage and 100 liters for the second stage. Within each stage, 40 polypropylene disks, $5 \mathrm{~mm}$ thick with a $0.61-\mathrm{m}$ diameter, were mounted on a stainless steel shaft with a disk spacing of $2.54 \mathrm{~cm}$ in Stage 1 and $1.27 \mathrm{~cm}$ in Stage 2. The disks were mounted such that $40 \%$ of the total disk area was submerged in the water. The disks were rotated at a peripheral disk speed of $4.04 \mathrm{~m} / \mathrm{min}$. As the disks rotated, microbial growths attached to the disks were alternately exposed to contaminants in the groundwater and the respective atmospheres maintained in the reactors. Figure 2 illustrates the two-stage design of the RBC.

Groundwater was fed directly to the first-stage reactor, perpendicular to the axis of rotation at a nominal rate of $800 \mathrm{~L} /$ day. The first stage was covered to prevent atmospheric contact and maintain anoxic conditions. First-stage effluent flowed by gravity to the second stage, which was maintained under aerobic conditions. Second-stage effluent was cycled back to the first stage at a

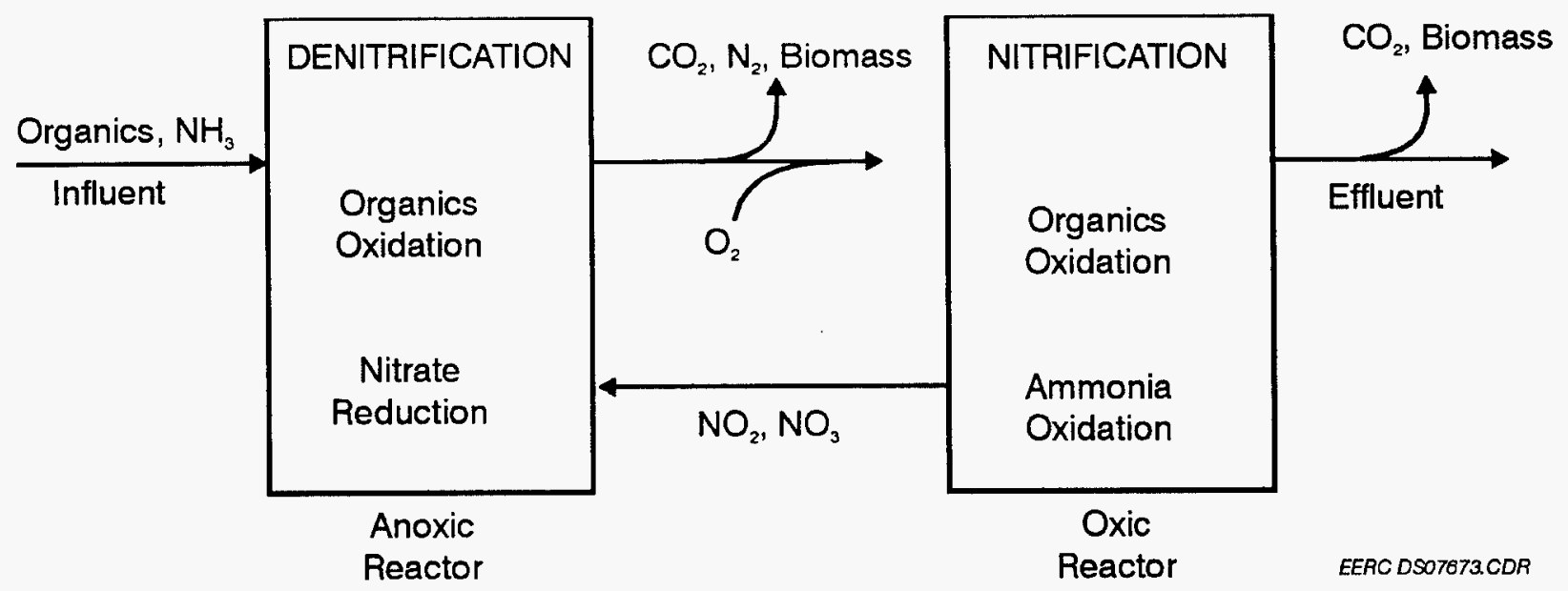

Figure 1. Conceptual nitrification-denitrification process diagram. 

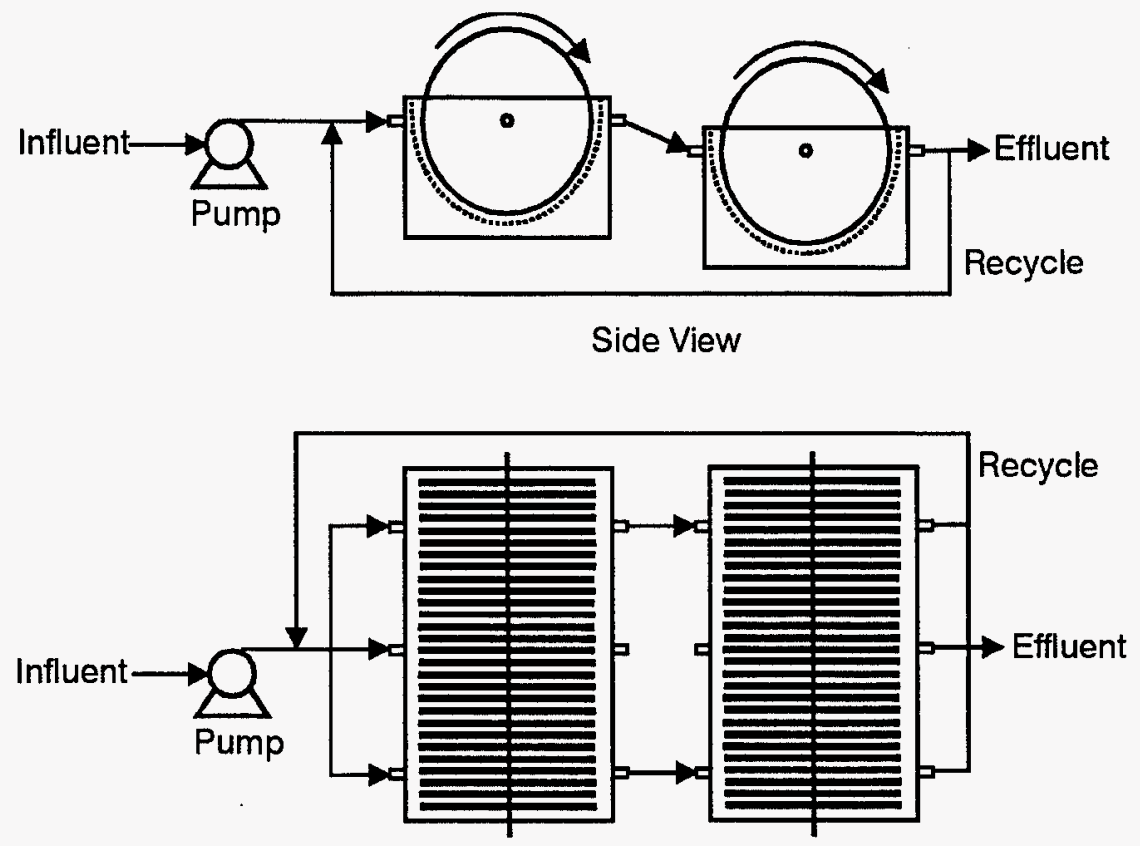

EERC DS14036.CDR

Top View

Figure 2. Two-stage RBC.

rate of $2000 \mathrm{~L} /$ day. Effluent flowed by gravity from the second stage and was discarded to a nearby drainage pond.

Groundwater used during treatability testing was taken from Recovery Wells RW-8, RW-9, and RW-13 at the Strachan Gas Plant and diverted into a 2000-L holding tank where it was mixed at a 25:25:50 ratio, respectively, and pumped into the first reactor. Prior to data collection for treatability evaluation, the two-stage RBC system was operated for a period of approximately 21 days to allow for the development of an acclimated population of microorganisms. Influent to the system during acclimation consisted of a 50:50 mixture of groundwater from RW-8 and RW-9. A 25:25:50 ratio of RW-8, RW-9 and RW-13, respectively, was subsequently maintained throughout the remainder of treatability testing.

Daily maintenance was performed on the RBC treatment system throughout the 105-day period of operation. Routine maintenance activities are summarized in Table 2.

\subsubsection{Results}

Groundwater treatment was evaluated under a single operating condition. During the period of operation, influent was fed to the system at a nominal rate of $800 \mathrm{~L} /$ day. This corresponded to a single-stage hydraulic loading rate of $34.5 \mathrm{~L} / \mathrm{m}^{2}$-day of disk surface area and an average organic loading rate of $4482.7 \mathrm{mg} \mathrm{COD} / \mathrm{m}^{2}$-day disk surface area. The ammonia-loading rate was $1241.4 \mathrm{mg} / \mathrm{m}^{2}$-day. 
TABLE 2

Routine System Maintenance Performed During Strachan Groundwater Treatability Studies

\begin{tabular}{lc}
\hline Control Parameter & Frequency \\
\hline Measure of pH of Influent and Effluent & Daily \\
Measure of Reactor Temperatures & Daily \\
Measure of Dissolved Oxygen in Influent and Effluent & Daily \\
Measure and Adjustment of Influent Rate & $2 /$ week \\
Measure and Adjustment of Recycle Rate & $1 /$ week \\
Collection and Submittal of Samples for Analysis & $1 /$ week \\
\hline
\end{tabular}

Treatment results under these conditions are summarized in Table 3. Target organic constituents, benzene, toluene, ethylbenzene, and total xylenes were all reduced to below the detection limit of $1 \mu \mathrm{g} / \mathrm{L}$. Figure 3 illustrates total combined influent and effluent concentrations of BTEX over the entire period of operation. COD was reduced from an average $130-\mathrm{mg} / \mathrm{L}$ influent concentration to an average $67 \mathrm{mg} / \mathrm{L}$ in the effluent, a $48.5 \%$ reduction. Ammonia was reduced from $36 \mathrm{mg} / \mathrm{L}$ to $23 \mathrm{mg} / \mathrm{L}$, a $36.1 \%$ reduction. Because of low reactor temperatures, nitrification was not fully achieved. Therefore, the reduction of ammonia may be attributed to partial nitrification, volatilization, and the microbial need for nutrients such as nitrogen and phosphorus. Given a biochemical oxygen demand to nitrogen $\left(\mathrm{BOD}_{5}: \mathrm{N}\right)$ ratio of $100: 5$, approximately $23 \%$ of the ammonia loss could be accounted for as a nutrient supplement.

TABLE 3

RBC Treatability Test Results at 800-L/day Influent Rate

\begin{tabular}{lccc}
\hline Parameter & Average Influent & Average Effluent & Percent Removal \\
\hline $\mathrm{pH}$ & 7.4 & 8.6 & - \\
$\mathrm{BOD}_{5}, \mathrm{mg} / \mathrm{L}$ & 40.8 & 9.3 & 77.2 \\
$\mathrm{COD}, \mathrm{mg} / \mathrm{L}$ & 130 & 67 & 48.5 \\
Ammonia, $\mathrm{mg} / \mathrm{L}$ & 36 & 23 & 36.1 \\
Nitrate, $\mathrm{mg} / \mathrm{L}$ & 0.4 & 1.2 & - \\
Benzene, $\mu \mathrm{g} / \mathrm{L}$ & 310 & $<1$ & $>99.6$ \\
Toluene, $\mu \mathrm{g} / \mathrm{L}$ & 69 & $<1$ & $>98.5$ \\
Ethylbenzene, $\mu \mathrm{g} / \mathrm{L}$ & 431 & $<1$ & $>99.7$ \\
Xylenes (total), $\mu \mathrm{g} / \mathrm{L}$ & 8250 & $<1$ & $>99.9$ \\
\hline
\end{tabular}




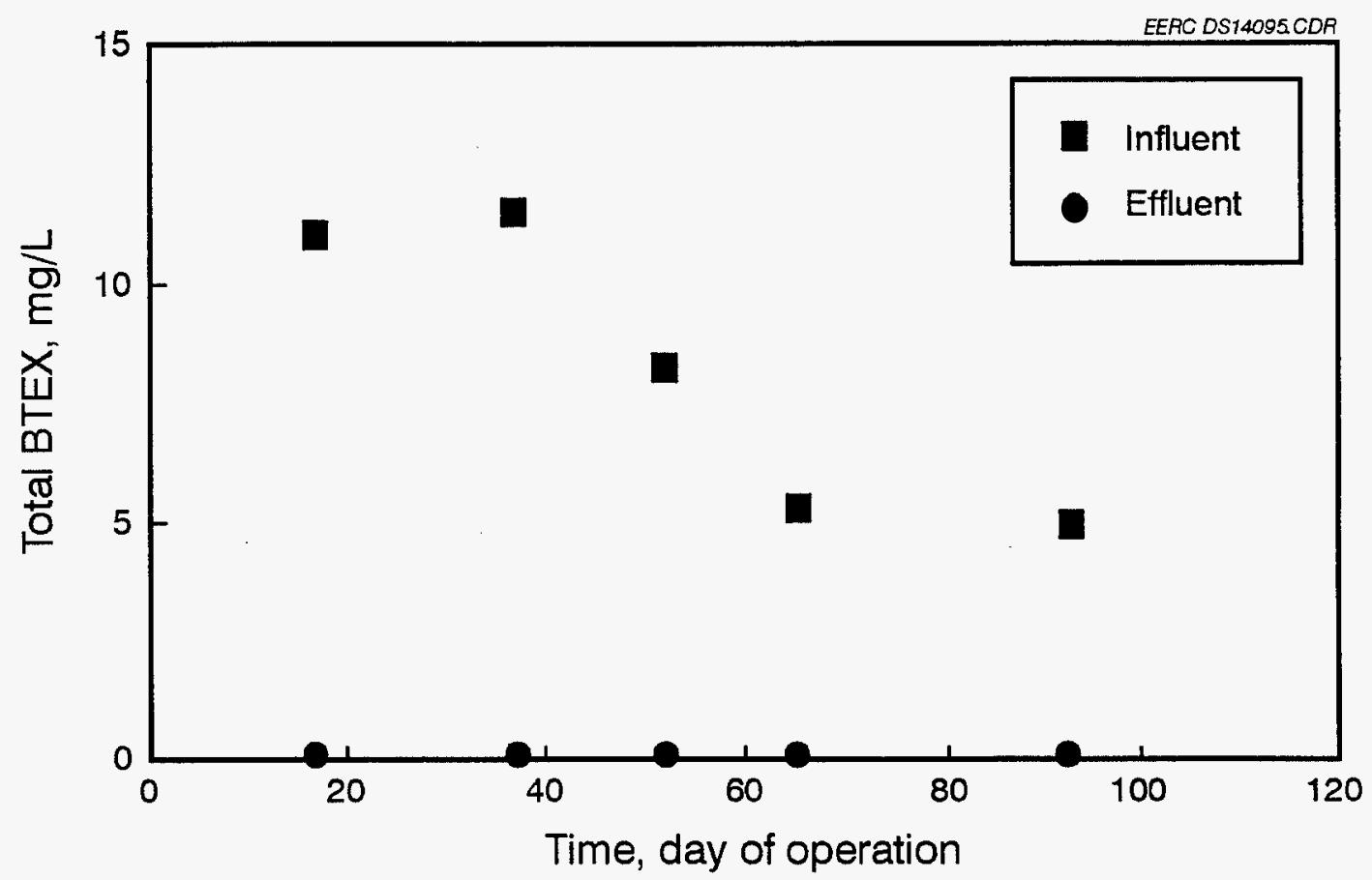

Figure 3. BTEX influent and effluent concentrations versus time at 800-L/day feed rate in Year 1.

\subsection{Year 2 Treatability Testing}

\subsubsection{Equipment Description and Operation}

The second year of the pilot-scale field demonstration consisted of the same two-stage RBC unit as in Year 1, with slight operating modifications. The groundwater pumping configuration had changed at the site, and RW-8 and RW-9 were the active recovery wells. Therefore, the approach of the second year of testing consisted of determining the highest achievable level of BTEX removal. Because of the low levels of ammonia in RW-8, as seen in Table 1, nitrification treatment was not needed in Year 2.

Groundwater used during treatability testing was taken from Recovery Wells RW-8 and RW-9, without the addition of RW-13, directly off-line from the current pump-and-treat system prior to treatment. During treatability testing, influent consisted of groundwaters from RW-8 and RW-9, and mixed at a 50:50 ratio.

Biomass was allowed to acclimate naturally on the disks. The influent feed rate was gradually increased to the $1800-\mathrm{L} /$ day operating rate over a period of approximately 3 weeks. After this period of time, laboratory analyses were performed to evaluate system performance and determine nutrient requirements. Sample analyses for both Years 1 and 2 were performed by CHEMEX Laboratories, Inc., in Calgary, Alberta.

The system was operated at a nominal rate of $1800 \mathrm{~L} /$ day for 22 days, followed by a steadystate sampling and analysis period. The influent rate was then increased to approximately $2800 \mathrm{~L} /$ day for the remainder of the demonstration. A nutrient solution of ammonium bicarbonate 
and ammonium phosphate was added daily to the influent to provide the necessary $100: 5: 1$, BOD:N:P ratio required for successful microbial degradation of the influent compounds. This addition was necessary because of the absence of $\mathrm{RW}-13$ which contained most of the ammonia that was present in Year 1.

Daily maintenance was performed on the RBC treatment system throughout the 107-day period of operation. Routine maintenance activities were identical to Year 1, as summarized in Table 2.

\subsubsection{Results}

The two-stage RBC system was operated for a period of approximately 3 weeks to allow for the development of an acclimated population of microorganisms and provide stable system operation. A seed microbial population was added on Day 2 to promote initial growth. Influent to the system during acclimation consisted of a 50:50 mixture of groundwater from RW-8 and RW-9.

Groundwater treatment was evaluated under two steady-state operating conditions. During the first period of steady-state operation, influent was fed to the system at a nominal rate of $1800 \mathrm{~L} /$ day. This corresponded to a single-stage hydraulic loading rate of $77.6 \mathrm{~L} / \mathrm{m}^{2}$-day of disk surface area and an average organic loading rate of $5237.5 \mathrm{mg} \mathrm{COD} / \mathrm{m}^{2}$-day disk surface area. The BTEX loading rate was determined to be an average of $853.5 \mathrm{mg} \mathrm{BTEX} / \mathrm{m}^{2}$-day. Treatment results under these conditions are summarized in Table 4. Target organic constituents, benzene, toluene, ethylbenzene, and total xylenes are all being reduced to below the detection limit of $1 \mu \mathrm{g} / \mathrm{L}$. COD was reduced from an average $68-\mathrm{mg} / \mathrm{L}$ influent concentration to an average $23 \mathrm{mg} / \mathrm{L}$ in the effluent, a $66.2 \%$ reduction.

\section{TABLE 4}

RBC Treatability Test Results at 1800-L/day Influent Rate

\begin{tabular}{lccc}
\hline Parameter & Average Influent & Average Effluent & Percent Removal \\
\hline $\mathrm{pH}$ & 7.4 & 8.3 & - \\
$\mathrm{COD}, \mathrm{mg} / \mathrm{L}$ & 68 & 23 & 66.2 \\
Benzene, $\mu \mathrm{g} / \mathrm{L}$ & 750 & $<1$ & $>99.7$ \\
Toluene, $\mu \mathrm{g} / \mathrm{L}$ & $<180$ & $<1$ & $>99.5$ \\
Ethylbenzene, $\mu \mathrm{g} / \mathrm{L}$ & 510 & $<1$ & $>99.8$ \\
Xylenes (total), $\mu \mathrm{g} / \mathrm{L}$ & 1100 & $<1$ & $>99.9$ \\
\hline
\end{tabular}

Following steady-state sampling and analysis at an 1800-L/day feed rate, the influent rate was increased by approximately $150 \mathrm{~L} /$ day over 7 days until a $2800-\mathrm{L} /$ day feed rate was achieved. The $2800-\mathrm{L} /$ day influent rate corresponded to a single-stage hydraulic loading rate of $8146.4 \mathrm{~L} / \mathrm{m}^{2}$-day of disk surface area. The BTEX loading rate was determined to be an average of $1328.6 \mathrm{mg}$ $\mathrm{BTEX} / \mathrm{m}^{2}$-day. Treatment results under these conditions are summarized in Table 5. Target organic constituents, benzene, toluene, ethylbenzene, and total xylenes are all being reduced to below the detection limit of $1 \mu \mathrm{g} / \mathrm{L}$. 


\section{TABLE 5}

RBC Treatability Test Results at 2800-L/day Influent Rate

\begin{tabular}{lccc}
\hline Parameter & Average Influent & Average Effluent & Percent Removal \\
\hline $\mathrm{pH}$ & 7.4 & 8.3 & - \\
Benzene, $\mu \mathrm{g} / \mathrm{L}$ & 900 & $<1$ & $>99.8$ \\
Toluene, $\mu \mathrm{g} / \mathrm{L}$ & $<180$ & $<1$ & $>99.5$ \\
Ethylbenzene, $\mu \mathrm{g} / \mathrm{L}$ & 300 & $<1$ & $>99.6$ \\
Xylenes (total), $\mu \mathrm{g} / \mathrm{L}$ & 1356 & $<1$ & $>99.9$ \\
\hline
\end{tabular}

While operating at the $2800-\mathrm{L} /$ day feed rate, nutrient addition was eliminated for a period of 5 days to evaluate the system nutrient demand. During this period, effluent nitrogen, as ammonia, was reduced to $0.14 \mathrm{mg} / \mathrm{L}$ from an average $0.66 \mathrm{mg} / \mathrm{L}$. A corresponding increase in effluent BTEX concentrations, as shown in Figure 4, is evidence of the significance of nutrient addition.

\subsection{SUMMARY AND CONCLUSIONS}

Effective treatment of contaminated groundwater at the Strachan Gas Plant was demonstrated using a two-stage RBC. During the first year of the demonstration, the groundwater recovery configuration required that the removal of both dissolved petroleum hydrocarbons and ammonia were significant considerations. A coupled nitrification-denitrification RBC treatment system

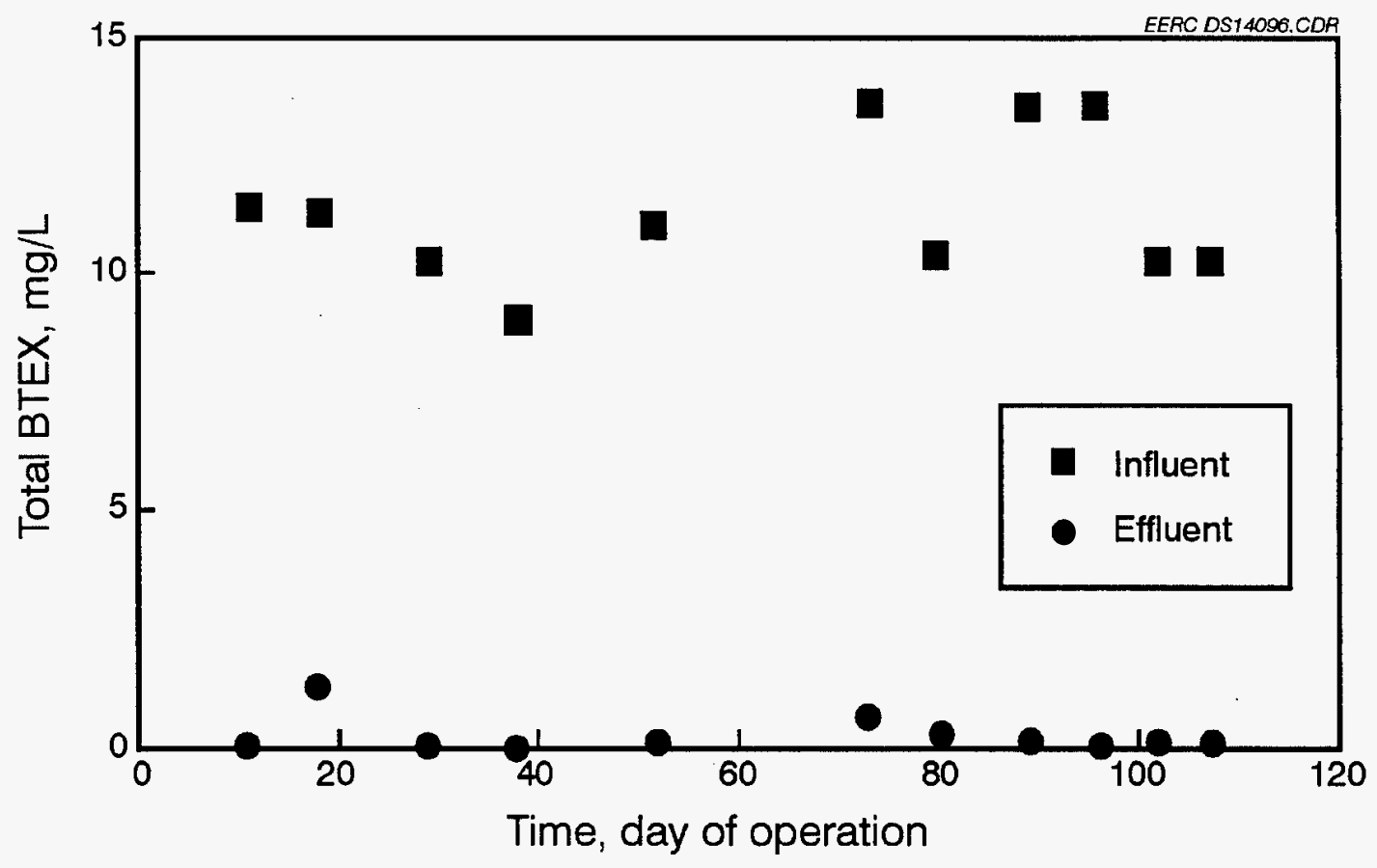

Figure 4. BTEX influent and effluent concentrations versus time at 1800 - and $2800-\mathrm{L} /$ day feed rate in Year 2. 
achieved high rates of organics removal, with limited ammonia removal. Nitrification was not established during the testing period and was attributed primarily to the cold operating temperatures and the limited time to establish an active population of nitrifying bacteria.

The second-year field demonstration focused on organics removal, specifically BTEX constituents, along with a determination of the necessity of nutrient addition. During steady-state operation under two different organic loading conditions, benzene, toluene, ethylbenzene, and xylenes were all removed to levels less than the detection limit of $1 \mu \mathrm{g} / \mathrm{L}$. The system exhibited stable operation, with no observed fouling or adverse scaling from the hardness constituents in the groundwater. When recovering groundwater from the recovery wells with low ammonia concentrations, nutrient addition to supplement both nitrogen and phosphorus was required. Maintaining a nutrient addition ratio of 100:5:1 $\mathrm{BOD}_{5}$ :nitrogen:phosphorus provided sufficient nutrients for effective BTEX removal.

RBCs are capable of providing effective treatment for contaminated groundwaters at natural gas treatment facilities without the need for any pretreatment to reduce hardness and other scalecausing constituents. When considering this form of treatment in northern climates, however, the treatment system should be housed in a heated building to allow for year-round operation. Since relatively low hydraulic retention times are required for effective removal of BTEX, the system operating temperatures remain quite low. It is anticipated that a heat exchanger would improve removal of ammonia through nitrification. However, care should be taken to reduce volatilization of the petroleum hydrocarbons.

\subsection{REFERENCES}

Canadian Council of Ministers of the Environment (CCME), 1991, Interim Canadian environmental quality criteria for contaminated sites: CCME EPC-C534.

Hach Company, 1980, Water analysis handbook, 2nd ed. Loveland, Colorado.

Reynolds, T.D., 1982, Unit operations and processes in environmental engineering.

U.S. Environmental Protection Agency, 1975, Process design manual for nitrogen control. 
M97005436

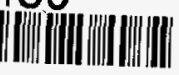

Report Number (14) DOE InC/30098- 5719

Jubl. Date (11) $\angle 9 Q 703$

sponsor Code (18) DOE/FE, XF

JC Category (19) $U C-101$, DOE/ER

DOE 